\title{
WILD UNGULATE POPULATION IN BAGHMARA BUFFER ZONE COMMUNITY FOREST, NEPAL
}

\author{
B.K. Sharma ${ }^{1}$, G.S. Solanki ${ }^{1}$ and M.K. Chalise $^{2}$
}

\section{ABSTRACT}

This study was conducted in Baghmara Buffer Zone Community Forest aiming to find out the ungulate population. Total complete count method was utilized by direct visual counting technique. The enumerator covered the entire forest by walking along the fixed bearing from one end to another end of the forest counting all ungulates. The animals were stalked and approached with minimum disturbance, counting and sex were confirmed with the help of binoculars. The current study recorded five species of ungulates. There were 12 resident Barking Deer, 2 Hog Deer, 23 Sambar, 4 Wild Boar and 182 Spotted Deer. The number of wild ungulates increased significantly $(\mathrm{T}=2.01, p<0.05, \mathrm{df}=8)$ in post-community management regimes $(n=224)$ than the pre-community management $(n=1)$.

Key words: Chitwan, population, prey, wild animals, pre and post management

\section{INTRODUCTION}

After the efforts of the conservation initiated before 20 years, Baghmara Buffer Zone Community Forest, located in Bachhauli Village Development Committee at eastern sector Buffer Zone area of Chitwan National Park, became a habitat suitable for different types of wild animals like ungulates and others. Lowland (sub-tropical) region of Nepal is famous for charismatic and diverse form of wildlife. The riverine subtropical forest with flood plain adds its richness in biodiversity. The commercial demand and the local marginalized peoples' needs have exerted pressure that has led to decrease its densities and their population outside the protected areas. However, the community forestry programs established by government and managed by local people outside the protected areas are the last refuse of biodiversity and specially of larger mammals as large size fauna is the first choice of poacher.

In 1963, the Baghmara forest was favorable habitat for tiger and rhinos and was also a hunting ground. Later due to extensive exploitation of the forest it was merely an unproductive barren wilder land for animals and plants. In 1988 Baghmara forest area was identified for conservation activities. At that time a few wildlife species existed but the information about them was scattered in different notes and papers only. Although the conservation initiative started in 1989, Baghmara Buffer Zone Community Forest was officially institutionalized in 1994 under the legislation of Department of Forest (BCF 1994). In 2003, this forest was registered as community forest according to buffer zone regulation based on the fourth amendment of the National Parks and Wildlife Conservation Act (in 1994). A systematic wildlife and vegetation study of this area was conducted for the first time in 1994 (NCRTC 1995) and thereafter it was monitored on regular basis. After more than 20 years of conservation efforts a healthy forest area with different habitat types was created and some endangered flagship species and other common large wildlife species were re-colonized (NCRTC 2000). 
This study was focused on the status of ungulate population in pre and post community management period. The information on restoration of ungulate population during these 20 years has compared comprehensively. During the pre community management period less security was added with open grazing practices and available space was not supportive for the diversity of wild animal and their population. The study will describe the large mammalian species available in Baghmara Buffer Zone Community Forest and increase in their population during 1995 and 2011.

\section{STUDY AREA}

Baghmara Buffer Zone Community Forest is located in Bachhauli Village Development Committee at eastern sector Buffer Zone area of Chitwan National Park, Nepal. It is situated in between $27^{\circ} 34.78^{\prime}-27^{\circ} 35.53^{\prime}$ northern latitude and $84^{\circ} 28.43^{\prime}-84^{\circ} 29.40^{\prime}$ eastern longitude in subtropical region of central lowland Nepal at an elevation of 170 to 250 meter above sea level. This forest borders cultivated land to east, Budhi Rapti river to west and north and Bodreni village and Rapti river to south. Baghmara forest is divided into five vegetation types based on composition and predominant plant species namely (a) Acacia catechu forest, (b) Albizia lucidior forest, (c) Savanna grassland, (d) Dalbergia sissoo forest and (e) Trewia nudiflora forest. The climate is sub-tropical with monsoon having relatively high humidity. Annual average rainfall (2000-2010) of the area is $2212.3 \mathrm{~mm}$. Average maximum and minimum temperature of the area is $30.9^{\circ} \mathrm{C}$ and $18.2^{\circ} \mathrm{C}$. The area included three main climatic seasons namely, pre-monsoon, monsoon, post-monsoon. This area consists of riverine areas with five types of forests. The forest provided excellent habitats for different wildlife including endangered Rhinoceros unicornis (Sharma et al. 2011, 2012).

\section{MATERIALS AND METHODS}

Total complete count method of animal was conducted once by direct visual counting technique (Gopal 1992). To reduce the double counting and missing of some animal in count the enumerators were placed in such a way that they are able to see the enumerators in their left and right. The enumerator covered the entire forest by walking along the fixed bearing from one end (baseline) to another end of the forest and counting all ungulates. In total 18 transects traversing the entire forest were prepared for the census. The size of transects was set in such a way that it can be covered by 18 enumerators, spaced at least a distance of 100 meters, within an hour. The animals were stalked and approached with minimum disturbance, counting and sex was confirmed with the help of binoculars. Three enumerators were waiting in the tree platform as vantage point at the end of forest to count the escaped animal during census.

This area was completely fenced around three sides, only western part was bordered by river. Therefore, animals were driven in such a way that chances of escaping animals from the sight of enumerator was not possible. Considering entire community forest as one census unit, total count was performed to all ungulates. Prior to start briefing about the counting techniques and the area to be counted was delivered to all technicians. A starting point was identified and 23 technicians (including 5 elephant drivers) spaced at intervals of 100 meters were placed. They are instructed to move quietly through the jungle with compass bearing on hand and record sighted ungulates. All technicians had watches that were set to the watch of the drive count 
coordinator. Data on time, species, age, sex, number and location with reference to the line of travel and direction of movement of the wildlife were recorded. Total counting of wildlife was conducted in early morning. During counting the enumerators also took note of those animals which were seen to their left and right. Details of wildlife regarding approximate age, sex and other evidences were recorded.

Secondary information related to ungulate population was collected from different sources. Published documents like annual reports, technical reports and management plans were the main source of secondary information collection. The collected information were analyzed by using Microsoft excel and Minitab version 15. Secondary data from other research works were also used for analysis. Wherever possible the collected data were analyzed by different statistical tests like means, medians and significant tests (Johnson and Bhattacharya 1996). T-test was used to analyze whether the ungulate population increased significantly in postmanagement than the pre-management regime or not. The population increment factor was calculated by dividing the wildlife population of post-management by the wildlife population of pre-management regime.

\section{RESULTS AND DISCUSSION}

The management periods as well as population of wildlife categories were evaluated on the basis of more than 20 years of conservation efforts. That included: a) pre-community managed period from 1989 to 2000, and b) post-community managed period from 2001 to 2011 .

Ungulate species in Baghmara Buffer Zone Community Forest consists of Barking deer (Muntiacus muntjack), Hog deer (Axis porcinus), Sambar (Cervus unicolor), Spotted deer (Axis axis) and Wild boar (Sus scrofa). A detail of population composition in terms of age and sex is given in table 6 .

Twelve resident Barking deer, 2 Hog deer, 23 Sambar and 182 individuals of Spotted deer were recorded. Details of population composition in terms of age and sex are given in table 6. Only one resident Wild Boar group was recorded from Baghmara Buffer Zone Community Forest. Total population of this species was five with more juvenile male $(n=4)$ and only one adult female. As Wild boar group was recorded with juveniles that indicated presence of adult male but it was not observed.

Table1. Population with age and sex composition of prey species in the study area (2011).

\begin{tabular}{|l|l|l|l|l|l|l|l|l|l|}
\hline \multirow{2}{*}{ Wildlife species } & \multicolumn{7}{|c|}{ Age / Sex / number } & \multirow{2}{*}{$\begin{array}{c}\text { Total } \\
\text { number }\end{array}$} \\
\cline { 2 - 11 } & AM & AF & SM & YAF & JM & JF & Infant & UN & 12 \\
\hline Muntiacus muntjack & 8 & 2 & - & - & - & - & 1 & 1 & 2 \\
\hline Axis porcinus & 1 & 1 & - & - & - & - & - & - & 23 \\
\hline Cervus unicolor & 7 & 13 & - & 1 & 1 & - & 1 & - & 182 \\
\hline Axis axis & 43 & 63 & 8 & 5 & 7 & 8 & 13 & 35 & 5 \\
\hline Sus scrofa & - & 1 & - & - & 4 & - & - & - & 5 \\
\hline
\end{tabular}

Note: $\mathrm{AM}=$ adult male; $\mathrm{AF}=$ adult female; $\mathrm{SM}=$ sub-adult male; $\mathrm{YAF}=$ young adult female; $\mathrm{JM}=$ juvenile male; JF=juvenile female; $\mathrm{UN}=$ unidentified 
During pre-community management period only one ungulate species of Sambar was recorded from the area (BCF 1994). Spotted deer was recorded only in 2001 (KMTNC 2001). The current study recorded five species of ungulate namely Barking deer, Hog deer, Sambar, Spotted deer and Wild boar. Their number increased significantly $(T=2.01, p<0.05, d f=8)$ in post community management regimes $(n=224)$ than the pre-community management $(n=1)$.

Table 2. Populations of wild animals in pre and post management regimes (1995 to 2011).

\begin{tabular}{|c|c|c|c|c|c|c|c|c|c|c|c|c|c|c|c|c|c|}
\hline \multirow{3}{*}{$\begin{array}{l}\text { Name of } \\
\text { wildlife }\end{array}$} & \multicolumn{17}{|c|}{ Recorded year (1995 to 2011) } \\
\hline & \multicolumn{6}{|c|}{ Pre-community manage } & \multicolumn{11}{|c|}{ Post-community manage } \\
\hline & 95 & 96 & 97 & 98 & 99 & 00 & 01 & 02 & 03 & 04 & 05 & 06 & 07 & 08 & 09 & 10 & 11 \\
\hline Barking deer & - & - & - & - & - & - & - & - & - & - & - & - & - & - & - & - & 12 \\
\hline Hog deer & - & - & - & - & - & - & - & - & - & - & - & - & - & - & - & - & 2 \\
\hline Sambar & 1 & - & 1 & - & - & - & - & - & - & - & - & - & - & - & - & - & 23 \\
\hline Spotted deer & - & - & - & - & - & - & 24 & - & - & - & - & - & - & - & - & - & 182 \\
\hline Wild boar & - & - & - & - & - & - & - & - & - & - & - & - & - & - & - & - & 5 \\
\hline
\end{tabular}

The previous study indicated that this area was quite favorable habitat for large and charismatic wild mammals (NCRTC 1995). Before the fifties the heavy anthropogenic pressure in the form of hill migration, agriculture extension, overgrazing and illegal logging of trees, reduced the wildlife population heavily (NCRTC 1990).

Current study recorded four Deer species, such as Spotted deer, Barking deer, Hog deer and Sambar from Baghmara forest. There were no earlier reports about their presence in the area. Barking deer are solitary animals and observed mostly single along the shady areas of dense forest habitat (Chalise 2001). Any record regarding its presence and absence was lacking in the pre-management regime of this community forest. This area was much disturbed due to heavy grazing by cattle of surrounding villages and other activities of local community that would have caused the disturbance or removal of wildlife during the pre management phase.

Presence of Hog deer in the study area indicated the availability of suitable habitats. Its general distribution indicated its solitary nature in alluvial grassland (Mishra 1982), and the floodplain grassland of BBZCF. In the pre-management phase there was not a single record of this species in this area (NCRTC 1995). Current monitoring result indicated its availability $(n=2)$ at the edge of oxbow lake rather than from floodplain. There was no report of Sambar presence at the initial stage of community management (NCRTC 1995). Only one Sambar was reported for the first time in the study area during 1995. Population count of this species was discontinued from its first record. The conservation of favorable habitats, like forests, grassland and wetlands inside the study area lead to increase $(n=23)$ the population of this mammal, in the post community management period. 
The population of spotted deer seemed a good in post-community regime whereas no residential Spotted Deer recorded during the initial phase of community forest management. They may be then frequent visitor from nearby Park Forest. Wildlife count in 2000 , immediately after flooding, reported 24 Spotted deer in the area (KMTNC 2001). This was the first official record of this species from the Baghmara area. Then the systematic count of this species was the current study only after a decade, which recorded 182 individual Spotted deer. Proper management of the available spaces (BBZCF 2003), regular patrolling and permanent sources of water (KMTNC 2001) in the area favor the wildlife to recolonize in the area. Density of five wild ungulates in the study area was 104.2 individuals $/ \mathrm{km}^{2}$, more than two hundred times higher than the pre-community manage period. The increment was mainly due to the remarkable increase the population of Spotted deer and Sambar as the habitat flourished.

There was significant increase in ungulate species population in post-management than premanagement phase $(T=2.01, p<0.05, d f=8)$. In the study area population of wild ungulates was increased by a factor of 11.2 in 20 years of community forest management. The number of ungulates in the study area was 0.5 animals $/ \mathrm{km}^{2}$ in $1995 / 1996$ and increased to 104.2 animals/ $\mathrm{km}^{2}$. Increase in abundance was due to remarkable change in population of all five ungulates. The frequent patrolling from the forest guards and the users' group members provided safeguard to the wildlife. Regular patrolling inside the forest helped to reduce the disturbances to the wildlife. Poaching of the ungulate species was not reported since its management from the community. These all factors in association with the improved condition of the habitats with regular sources of water favor to increase the abundance of wild ungulates in the study area.

\section{ACKNOWLEDGEMENTS}

Department of National Parks and Wildlife Conservation, Nepal is acknowledged for providing research permission. Baghmara Community Forest for providing research permission, Biodiversity Conservation Center for providing some logistics, Harkaman Lama and Jeevan Lama field technicians, Manoj Chaudhari secretary of BBZCF are highly acknowledged for the kind support. Local people are acknowledged for providing required information of this study.

\section{REFERENCES}

BBZCF, 2003. Operational Plan of Baghmara Buffer Zone Community Forest 2003 to 2007. Baghmara Buffer Zone Community Forest (BBZCF), Chitwan, Nepal.

BCF, 1994. Operational Plan of Baghmara Community Forest 1995 to 2000. Baghmara Community Forest (BCF), Chitwan, Nepal.

Chalise, M. K., 2001. Nepalka Banyajantu, Bhag 2 (Nepal's Wildlife, Part 2).Natural History Society of Nepal, Nepal (in Nepali).

Gopal, R., 1992. Fundamentals of Wildlife Management. Justice Home, India.

Johnson, R. A. and Bhattacharyya, G. K., 1996. Statistics: Principles and Methods. John Wiley and Sons, New York, USA.

KMTNC, 2001. Wildlife habitat extension in the buffer zone of the Royal Chitwan National Park. Final technical report, World Wildlife Fund-Nepal Program, King Mahendar Trust for Nature 
Conservation (KMTNC), Nepal.

Mishra, H. R., 1982. The ecology and behaviour of Chital (Axis axis) in the Royal Chitwan National Park, Nepal. The Ph.D. thesis, University of Edinburgh, UK.

NCRTC, 1990. Newsletter of NCRTC. KMTNC, Nepal Conservation Research and Training Centre (NCRTC), Nepal.

NCRTC, 1995. Promoting local guardianship of endangered species and wildlife habitat in Royal Chitwan National Park, Nepal. Progress report, Biodiversity Conservation Network, Nepal Conservation Research and Training Centre (NCRTC), Nepal.

NCRTC, 2000. Wildlife habitat extension in the Buffer Zone of the Royal Chitwan National Park. Final technical and financial report, WWF Nepal program, Nepal Conservation Research and Training Centre (NCRTC), Nepal.

Sharma, B. K., M. K. Chalise and G. S. Solanki, 2011. Large wildlife population in Baghmara Buffer Zone Community Forest, Nepal. Ecoprint, 18:55-62.

Sharma, B. K., M. K. Chalise and G. S. Solanki, 2012. Vegetation types and wildlife occurrence in Baghmara buffer zone community forest, Nepal. International Multidisciplinary Research Journal, 2(2):52-65.

\section{Abbreviations}

BCF - Baghmara Community Forest, BBZCF - Baghmara Buffer Zone Community Forest, KMTNC - King Mahendra Trust for Nature Conservation, NCRTC - Nepal Conservation Research and Training Center

\section{AUTHOR'S ADDRESS}

Bhuvan Keshar Sharma ${ }^{1}$ and Ghana Shyam Solanki ${ }^{1}$

Mizoram University, Tanhril 796 004, Aizawl, Mizoram, India

(email: bhuvan_keshars@hotmail.com)

Mukesh Kumar Chalise ${ }^{2}$

Central Department of Zoology, Tribhuvan University, Kirtipur, Kathmandu, Nepal 